\title{
Key lessons from resistant tree breeding programmes in the Northern Hemisphere
}

\author{
Paul Woodcock $^{1}$ (D) Mariella Marzano ${ }^{2} \cdot$ Christopher P. Quine $^{2}$ \\ Received: 28 August 2018 / Accepted: 25 March 2019 / Published online: 7 May 2019 \\ (C) Crown 2019
}

\begin{abstract}
- Key message To inform emerging initiatives, we explored five programmes that aimed to develop trees resistant to specific pests or pathogens. These case studies show resistant tree programmes are a medium to long-term approach requiring sustained investment, and can encounter substantial difficulties in developing and maintaining resistance. Equally, adequately resourced and well-planned programmes have resulted in operational deployment of resistant trees. - Context Developing trees that are resistant to specific pests and pathogens is an increasingly prominent strategy for responding to this escalating threat. It is therefore important to ensure decisions to use resistant trees and approaches to development are wellinformed.

- Aims We aimed to provide insights for newer or proposed resistant tree breeding programmes by identifying key lessons from earlier programmes, some of which date back several decades.

- Methods We selected five mature programmes as case studies, and in each case synthesised information from key publications and by following citations to original sources. We examined the objectives, methods, problems, successes and timescales in each programme.

- Results Resistant tree breeding is generally a medium to long-term approach requiring sustained investment and coordination, although culturally valued species can attract considerable support from volunteers. Deployment of resistant trees often recommends maintaining genetic variation and mixing with other tree species. Substantial costs and loss of confidence in future material can arise if resistance breaks down or resistant material is susceptible to other threats.

- Conclusion The case studies illustrate success is not guaranteed, but also provide evidence that adequately resourced and well-planned resistant tree programmes can contribute to strategies to mitigate impacts from pests and pathogens.
\end{abstract}

Keywords Tree breeding $\cdot$ Fungi $\cdot$ Herbivore $\cdot$ Insect $\cdot$ Disease $\cdot$ Forest management

\section{Introduction}

Handling Editor: Cécile Robin

Contribution of the co-authors All authors designed the research and contributed to the selection of case studies and decisions over what information to extract. PW wrote the initial draft, and all authors commented on and discussed revisions.

Paul Woodcock

Paul.Woodcock@jncc.gov.uk

1 Joint Nature Conservation Committee, Monkstone House, Peterborough PE1 1JY, UK

2 Forest Research, Northern Research Station, Roslin, Midlothian EH25 9SY, UK
Pathogens and arthropod herbivores are integral parts of natural forest ecosystems but can also cause widespread damage and mortality in managed and unmanaged forests. These impacts can be very severe, particularly where trees have few evolved defences because the pathogen or herbivore is not present within the native range of the tree (Boyd et al. 2013; Brasier 2008). For example, the Asian fungal pathogen chestnut blight (Cryphonectria parasitica [Murr.] Barr) killed billions of chestnut trees (Castanea dentata [Marsh.] Borkh.) following accidental introduction to North America, causing fundamental shifts in the composition and functioning of forest ecosystems and removing a potentially valuable timber 
resource (Jacobs 2007; Jacobs et al. 2013). Native pests and pathogens can also have important sustained or periodic impacts with high levels of mortality and damage (Aukema et al. 2006). The risks from non-natives are increasing as globalised trade networks facilitate spread, and the impacts from both native and non-native organisms may be amplified by other anthropogenic influences (Pautasso et al. 2012). Reflecting the scale of past and potential future impacts, combating pests and pathogens is thus an increasingly important concern (Freer-Smith and Webber 2015).

Although preventing and controlling pest and pathogen spread is important, this is often only a partial solution. As such, developing trees that are resistant to specific organisms is receiving new impetus - e.g. preliminary evidence that some ash trees may be less susceptible to ash dieback (Hymenoscyphus fraxineus [T. Kowalski] Baral, Queloz, Hosoya) is stimulating interest in several countries in using these trees to breed a resistant population (Defra 2013; Vasaitis and Enderle 2017). It is therefore important to understand where and how resistant tree programmes can be most effectively implemented and what the expectations should be. Note that for brevity, we refer to 'resistant tree programmes' - this potentially encompasses several related concepts (Sniezko and Koch 2017), including complete resistance (trees are fully resistant to a given organism and suffer minimal impacts), partial resistance (trees have mechanisms to reduce attack but suffer some impacts) and tolerance (trees get attacked/infested and display symptoms, but are nonetheless able to maintain growth and performance more effectively than less tolerant individuals).

Insights from recent review articles can help to inform decisions on whether resistant tree programmes should be pursued elsewhere, and on what the approaches, requirements and expectations should be. For example, Sniezko and Koch (2017) highlight the opportunities and challenges presented by the emergence of new technology such as improved DNA sequencing methods and (potentially) genetic engineering, whilst Woodcock et al. (2018) describe a general framework for the processes and decisions involved in developing and using resistant trees, from initial screening through to operational deployment. Whilst recognising the potential importance of resistant trees, both studies also note the need to learn from previous experiences. However, the key events in resistant tree programmes are often dispersed across many publications. Furthermore, there is relatively little direct comparison amongst programmes of the different approaches used, or evaluation of why some efforts appear to have been more successful or rapid than others. Such comparisons could help guide the strategies of emerging and proposed resistant tree programmes, particularly if accompanied by timelines indicating key events. As such, here we investigate several case studies from temperate and boreal systems, and ask the following questions:

(i) What different approaches are used for screening, developing, producing and deploying resistant trees, and how are these influenced by biological factors (e.g. frequency of resistance within tree population) and stakeholder motivations (e.g. ecological vs. economic)?

(ii) What are the timescales over which key events in resistant tree programmes occur?

(iii) What problems have been experienced by resistant tree programmes, and what strategies have been used to mitigate these problems?

(iv) What factors influence the success of resistant tree programmes?

\section{Methods}

\subsection{Selecting case studies}

We aimed to identify resistant tree programme case studies from temperate or boreal systems that collectively encompassed the following criteria:

- Tree breeding against pests and against pathogens

- Tree breeding against native and against non-native threats

- Conifer and broadleaf species

- Differing motivations for tree breeding programme (e.g. economic, ecological, cultural etc.)

We focused on case studies that have been in place for several years, rather than less established programmes from which the ability to understand timescales, successes and problems is more limited. We also required programmes in which it was possible to clearly describe key stages and processes (see Data Extraction). To find case studies, we initially consulted a review carried out by the Food and Agriculture Organisation (FAO 2013) documenting the status of 274 resistant tree programmes (http://www.fao.org/forestry/26460/ en/). However, in the 2013 update of this review, many resistant tree programmes were incomplete (only 44 had established breeding programmes, of which 23 were planting material operationally). Furthermore, preliminary investigation of the literature linked by the FAO database illustrated wide variation amongst programmes in the amount of information provided and in the ease with which this could be accessed. As such, some resistant tree 
programmes are more tractable for detailed exploration than others, and more likely to generate useful insights.

To select case studies, we used a combination of the resources linked by the FAO database and our own knowledge to identify programmes that collectively encompassed the criteria outlined above and for which our initial investigations indicated that sufficient information could be obtained. Links and resources associated with this exploration are provided in Table 1 for information. The non-systematic nature of our case study selection means that our findings are illustrative of some of the different contexts, approaches, timescales and types of problems, rather than representative of all attempts to develop resistant trees. The case studies used were as follows: (1) American chestnut and chestnut blight - The American Chestnut Foundation, (2) American chestnut and chestnut blight-American Chestnut Co-operators Foundation, (3) Sitka spruce (Picea sitchensis [Bong.] Carr) and white pine weevil (Pissodes strobi Peck (Coleoptera: Curculionidae) British Columbia Ministry of Forests, (4) Western white pine (Pinus monticola Douglas ex D. Don) and white pine blister rust (Cronartium ribicola J.C. Fisch)—several programmes, and (5) several elm species (Ulmus spp.) and Dutch elm disease (Ophiostoma novo-ulmi [Brasier]) - Italian Institute of Plant Protection. Although we did not specifically exclude the Southern Hemisphere, the European and North American locations of our case studies mean that the findings are likely to be most informative in these systems.

\subsection{Data extraction}

To facilitate comparison between case studies, we extracted and collated data based on six steps previously identified as necessary components of resistant tree programmes (Woodcock et al. 2018; Table 2). The first step (1) describes the scope, context and objectives of the programme. Subsequent steps then detail the approach to (2) finding resistant trees, (3) breeding for resistance, (4) large-scale production, and (if relevant) (5) planting resistant trees in the field, and (6) subsequent monitoring of performance. We also gathered information on the timing of important events in the

Table 1 Tree-pest/pathogen systems from which case studies were selected. Not intended to be comprehensive (see http://www.fao.org/forestry/ $26460 / \mathrm{en} /$ for further examples). Also note that several programmes may not yet have reached deployment stage

\begin{tabular}{|c|c|c|}
\hline Tree species & Pest or pathogen & Programmes \\
\hline $\begin{array}{l}\text { American chestnut } \\
\text { (Castanea dentata) }\end{array}$ & $\begin{array}{l}\text { Chestnut blight } \\
\text { (Cryphonectria parasitica) }\end{array}$ & $\begin{array}{l}\text { The American Chestnut Foundation }{ }^{1} \\
\text { The American Chestnut Co-operators Foundation }{ }^{2} \\
\text { Connecticut Agricultural Experimentation Station } \\
\text { American Chestnut Research and Restoration Project }\end{array}$ \\
\hline $\begin{array}{l}\text { Sitka spruce } \\
\text { (Picea sitchensis) }\end{array}$ & $\begin{array}{l}\text { White pine weevil } \\
\text { (Pissodes strobi) }\end{array}$ & $\begin{array}{l}\text { British Columbia (B.C.) Ministry of Forests, Pacific Forestry Centre and B.C } \\
\text { universities }\end{array}$ \\
\hline Several susceptible Ulmus spp. & $\begin{array}{l}\text { Dutch elm disease } \\
\text { (Ophiostoma ulmi; } \\
\text { Ophiostoma novo-ulmi) }\end{array}$ & $\begin{array}{l}\text { Willie Commelin Scholten Phytopathological Laboratorium }{ }^{7} \\
\text { Italian Institute of Plant Protection } \\
\text { US Forest Service } \\
\text { University of Minnesota }^{7,10} \\
\text { Morton Arboretum }{ }^{7,11} \\
\text { The Great British Elm Search } \\
\end{array}$ \\
\hline Several susceptible Pinus spp. & $\begin{array}{l}\text { Blister rust } \\
\text { (Cronartium ribicola) }\end{array}$ & $\begin{array}{l}\text { US Forest Service } 13-15 \\
\text { B.C. Ministry of Forests }\end{array}$ \\
\hline $\begin{array}{l}\text { American beech } \\
\text { (Fagus grandifolia) }\end{array}$ & $\begin{array}{l}\text { Beech bark disease } \\
\text { (Nectria coccinea) }\end{array}$ & USDA $^{17,18}$ \\
\hline $\begin{array}{l}\text { Butternut } \\
\text { (Juglans cinerea) }\end{array}$ & $\begin{array}{l}\text { Butternut canker disease } \\
\text { (Sirococcus } \\
\text { clavigignenti-juglandacearum) }\end{array}$ & USDA $^{19-22}$ \\
\hline Several susceptible Pinus spp. & $\begin{array}{l}\text { Dothistroma needle blight } \\
\text { (Dothistroma spp.) }\end{array}$ & $\begin{array}{l}\text { CEH, Forestry Commission, Forest Research } \\
\text { CSIRO }^{24}\end{array}$ \\
\hline Several susceptible Fraxinus & Emerald ash borer & $\mathrm{USDA}^{25}$ \\
\hline $\begin{array}{l}\text { N. American hemlock species } \\
\text { (Tsuga } \text { spp.) }\end{array}$ & $\begin{array}{l}\text { Hemlock woolly adelgid } \\
\text { (Adelges tsugae) }\end{array}$ & $\mathrm{USDA}^{26-28}$ \\
\hline
\end{tabular}

Further information available at:

${ }^{1}$ The American Chestnut Foundation (http://www.acf.org). ${ }^{2}$ The American Chestnut Co-operators Foundation (http://www.accf-online.org).

${ }^{3}$ Connecticut Agricultural Experimentation Station (www.ct.gov/caes). ${ }^{4}$ College of Environmental Science and Forestry (http://www.esf.edu/chestnut).

${ }^{5}$ King et al. (2004). ${ }^{6}$ Alfaro et al. (2013). ${ }^{7}$ Mittempergher and Santini (2004). ${ }^{8}$ Santini et al. (2012). ${ }^{9}$ Townsend et al. (2005). ${ }^{10}$ University of Minnesota (https://www.legacy.mn.gov/projects/finding-disease-resistant-elm-trees-minnesota). ${ }^{11}$ Morton Arboretum (http://www.mortonarb.org/trees-plants/treeplant-descriptions/elm-cultivars). ${ }^{12}$ The Conservation Foundation (https://www.conservationfoundation.co.uk/elms). ${ }^{13}$ Fins et al. (2001). ${ }^{14}$ McDonald et al. (2004). ${ }^{15}$ Sniezko et al. (2008). ${ }^{16}$ British Columbia Ministry of Forests (http://www2.gov.bc.ca/gov/content/industry/forestry/managing-our-forestresources/tree-seed/forest-genetics/tree-breeding-improvement/western-white-pine). ${ }^{17}$ Koch (2010). ${ }^{18}$ Koch et al. (2012a). ${ }^{19}$ Michler et al. (2005). ${ }^{20}$ Woeste et al. (2009). ${ }^{21}$ McKenna et al. (2011). ${ }^{22}$ Boraks and Broders (2014). ${ }^{23}$ Perry et al. (2016). ${ }^{24}$ Ivkovic et al. (2011). ${ }^{25}$ Koch et al. (2012b).

${ }^{26}$ Bentz et al. (2008). ${ }^{27}$ Montgomery et al. (2009). ${ }^{28}$ Oten et al. (2014) 
Table 2 Intended information on resistant tree programmes to extract from case studies

\begin{tabular}{ll} 
Scope and objectives & Organisation(s) \\
& Region \\
& Tree species \\
& Pest or pathogen \\
& Severity \\
& Main impacts \\
& Programme objectives \\
& Estimated investment \\
Timescales and costs & $\begin{array}{l}\text { Programme start date } \\
\text { Status }\end{array}$ \\
Approach to screening & E.g. use of field surveys, planting trials etc. \\
Approach to tree breeding & E.g. conventional tree breeding, hybridisation etc. \\
Approach to producing & E.g. seed orchards, grafting etc. \\
material & Scale \\
Approach to deployment & Strategy \\
Approach to monitoring & E.g. long-term screening trials, field tests, volunteer-led \\
Problems & Noted problems and considerations \\
Complementary approaches & Other approaches promoted by organisation to improve success of resistant tree \\
& programme \\
\hline
\end{tabular}

programme, problems encountered and, where possible, costs. We obtained this information through key publications describing the status and/or plans for a given programme, supplemented by following any citations to original sources - the latter included journal articles, technical reports, newsletters and websites. The context for each case study is described in Box 1 and summarised in Table 3, with more detailed information in Tables 4 and 5.

Box 1 Context for selected resistant tree programmes

\section{American Chestnut (Castanea dentata)-chestnut blight (Cryphonectria parasitica)}

American Chestnut was a major part of eastern N. American forests with important effects on a range of ecosystem functions, as well as being a valuable timber source. However, the species was devastated by the accidental introduction of chestnut blight, a necrotrophic pathogen native to Asia that infects primarily through stem wounds. $C$. parasitica was first discovered in the USA in 1904 and spread rapidly causing very high mortality throughout the American Chestnut range. This had cascading impacts on forest structure, biodiversity and ecosystem functioning.

Comparing C. parasitica populations between North America and Europe (where it was also accidentally introduced) suggests there is greater genetic variation in the former. This is believed to reduce the effectiveness of hypovirulence as an alternative method of controlling the disease in N. America, and could have implications for resistance breeding. We focus on attempts to breed blight-resistant American Chestnut carried out by The American Chestnut Foundation (TACF) and by the American Chestnut Co-operators Foundation (ACCF).

European EIm species (Ulmus spp.)-Dutch EIm Disease (Ophiostoma ulmi, O. novo-ulmi)

Elms are generally fast-growing and particularly valued aesthetically. As such, the genus was used extensively in landscaping, including in urban areas with high levels of air pollution. However, two waves of Dutch Elm Disease (DED) had serious impacts on European and North American species. Thought to be native to Asia, the DED fungus is a vascular pathogen affecting several elm species and spread by the elm bark beetle. O. ulmi was first discovered in European elm species in the early twentieth century, and later accidentally introduced to N. America.

\section{Sitka spruce (Picea sitchensis)-pine weevil (Pissodes strobi)}

Sitka spruce is an important part of temperate North American forests. Its fast growth rate and good wood properties make it a commercially valuable timber species outside the native range. However, the use of Sitka spruce in North American forestry has been heavily constrained by the white pine weevil.

P. strobi is native to North America and does not generally kill trees. However, the resulting deformities reduce economic returns, and severe outbreaks can cause plantation failure due to poor wood quality. Genetic variation in $P$. strobi is high relative to other insects, and long-distance dispersal of the species appears to be rare. As such, there are several genetically distinct populations across the native range, some of which also contain substantial genetic diversity (Laffin et al. 2004). We focus on attempts to breed weevil-resistant Sitka spruce by the British Columbia Ministry of Forests.

\section{Western White Pine (Pinus monticola)-white pine blister rust (Cronartium ribicola)}

Western White Pine (WWP) was formerly widespread and ecologically important across mid-elevation forests in western North America. The species is well-adapted to seasonal climatic variation and is relatively fast-growing under suitable conditions, making it a potentially important timber species.

WWP is highly susceptible to White Pine Blister Rust (WPBR), a stem rust accidentally introduced from Europe in the early 1900s. Mortality to WPBR was very high, with WWP reduced to a fraction of its original 
(continued)

Although. O. ulmi had substantial impacts in N. America, it did not devastate populations in Europe. However, a more virulent strain (O. novo-ulmi) to which there was very little resistance emerged on both continents during the $1960 \mathrm{~s}$, killing millions of trees. O. novo-ulmi displaces the less virulent $O$. ulmi, and has also acquired beneficial genes from the latter through interspecific hybridisation (Bernier 2017). Distinct $O$. novo-ulmi subspecies are now documented, along with subspecies hybrids that are also spreading across Europe. This case study considers the DED-resistance breeding programme by the Italian Institute for Plant Protection (IPP): note there are several other programmes in Europe and North America (Table 1) cover by the 1960s. The WPBR pathogen has windborne spores that are particularly favoured by cool, moist conditions during summer and autumn. The life cycle of the organism also requires Ribes spp. Although introduced, WPBR is not genetically uniform, with outcrossing and (in more isolated populations) genetic drift contributing to genetic diversity. Genetic differences in WPBR affect virulence, and a variant strain of the pathogen is able to circumvent some mechanisms of resistance used in initial WWP tree breeding programmes. We decided to consider three North American programmes to breed for WPBR resistance, due to the overlap and linkages between these programmes.

\section{Results}

\subsection{Scope, objectives and co-ordination}

Some resistant tree programmes are co-ordinated and funded primarily by government forestry departments, whereas others have substantial NGO involvement (often with government support) or commercial interest. These groups are motivated by many factors, from the national cultural significance of the species (e.g. American chestnut; Jacobs et al. 2013) through to the commercial value from timber production (e.g. Sitka spruce; Alfaro et al. 2013) or potential benefits from patenting resistant material (e.g. European elms; Santini et al. 2012). In the case of American chestnut, public engagement and interest is an important standalone objective. Context also varies, with some programmes aiming to restore a species that has already suffered a major decline (e.g. American chestnut-chestnut blight programmes; Jacobs et al. 2013), whilst others focus on minimising ongoing impacts (e.g. Sitka spruce-pine weevil; Alfaro et al. 2013). These differences in motivation and context influence the resources available and the approaches taken in subsequent steps.

\subsection{Finding resistant trees}

Initial evidence of resistance in the case studies came from relatively ad hoc field observations. These early findings shaped subsequent work, either by identifying potentially resistant material for further trials (Alfaro et al. 2013) or informing an emphasis on resistant hybrids rather than relying on very rare within-species resistance (Santini et al. 2012; Jacobs et al. 2013). All the case studies used planting trials to further investigate potential resistance, often including susceptible families as controls (Sniezko et al. 2014). In some trials, the pest or pathogen is deliberately introduced to expedite the test and standardise comparison across sites, and heritability and geographic differences in resistance are explored (Alfaro et al. 2013). Trials also often revealed important complexity in the expression of resistance- - e.g. multiple resistance mechanisms influenced by environmental factors and tree age (Hebard 2005a; King et al. 2010). Lastly, the time, costs and land involved in planting trials are often substantial, meaning considerable resources and co-ordination can be necessary (Alfaro et al. 2013).

\subsection{Approaches to developing resistance}

Two general approaches were used to breed resistant trees. Where observations suggested some resistance, conventional breeding between individuals of the same species was preferred (e.g. rust resistance in Western White Pine [WWP] and weevil resistance in Sitka spruce; Alfaro et al. 2013; Sniezko et al. 2014). By contrast, the American chestnut and the elm breeding programmes use hybridisation between susceptible species and a resistant relative, reflecting evidence that very few individuals of the affected species appear resistant to these diseases. Tree breeding approaches are also shaped by the rationale for the programme, to the extent that more complex or time-consuming methods are sometimes preferred. For example, The American Chestnut Cooperators Foundation (ACCF) aims to develop blightresistant pure American chestnut (www.accf-online.org) despite the rarity of resistance within the species. The approach involves controlled crosses of surviving trees (as well as open pollination of survivors) coupled with the use of hypovirulent strains of $C$. parasitica for blight control (Griffin et al. 2005). Similarly, although The American Chestnut Foundation (TACF) produced a blight-resistant hybrid many years ago (Fig. 1; Diskin et al. 2006; Jacobs et al. 2013), the organisation is committed to restoring the ecological and cultural importance of American chestnut and so uses several generations of backcrossing (combining the hybrid with American chestnut parents) to recover characteristics of the pure species (Jacobs et al. 2013). Subject to regulatory approval, TACF also intend to incorporate genetically engineered trees into the breeding programme (Westbrook 2018). This material contains the oxalate oxidase gene, which confers resistance to $C$. parasitica by detoxifying oxalate produced by the pathogen (Steiner et al. 2017). Again however, rather than plant genetically engineered trees immediately, TACF plan to use further breeding to dilute the contribution from the modified clone, as well as to incorporate resistance 
Table 3 General characteristics of each case study. Black cells indicate a characteristic is highlighted by a given programme, grey cells: partly relevant, white cells: not highlighted in the literature consulted

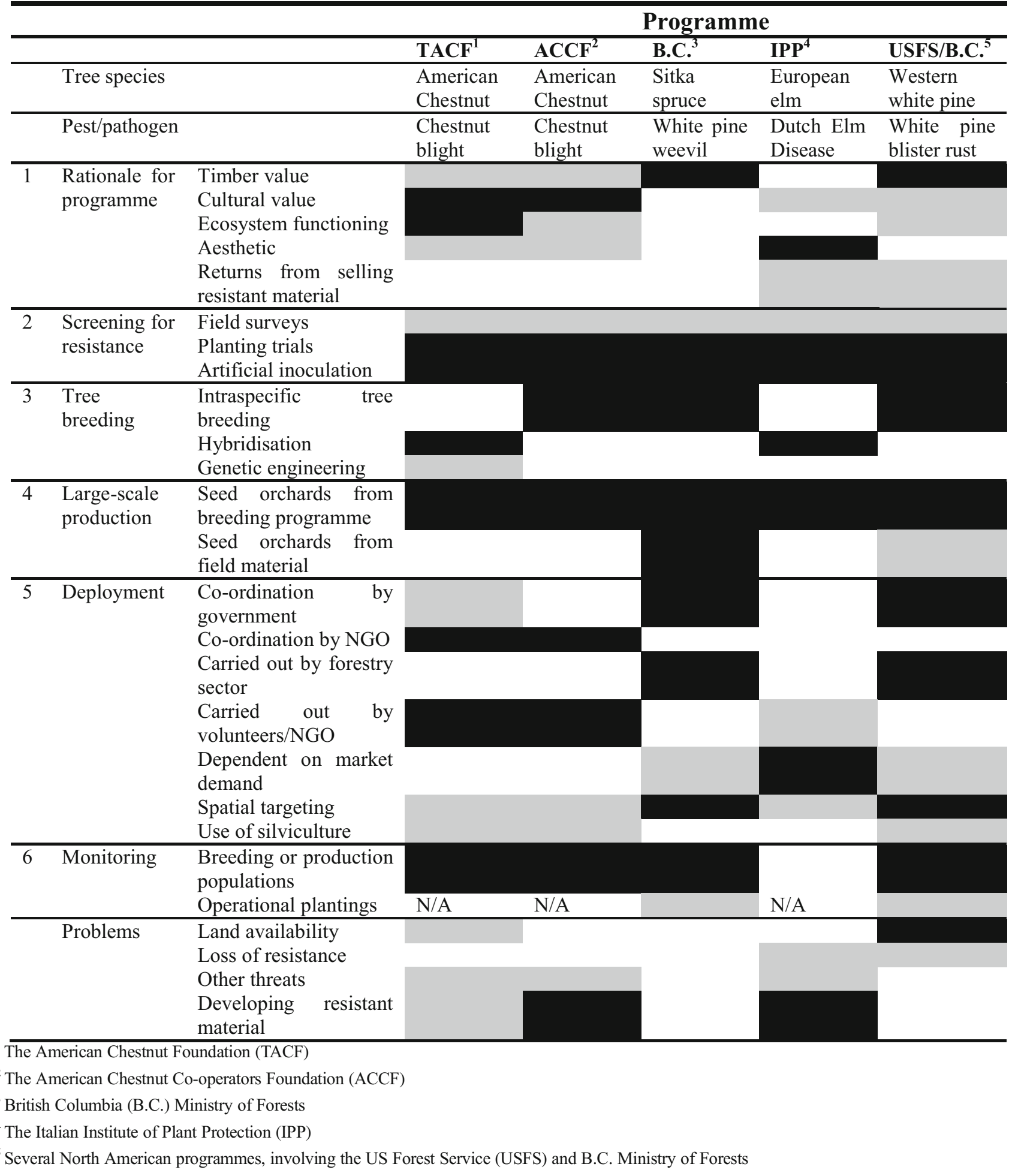

from hybrids and to ensure a genetically diverse population - trees from this additional breeding are predicted to be available for operational planting between 2030 and 2050 (Westbrook 2018). Other breeding programmes also aim to identify and include trees that encompass several mechanisms of resistance and are genetically distinct from each other. For example, several forms of WPBR resistance have been documented in WWP (e.g. few infection spots, cankers absent or slower-growing, shed of infected needles; King et al. 2010). Combining these apparently distinct 


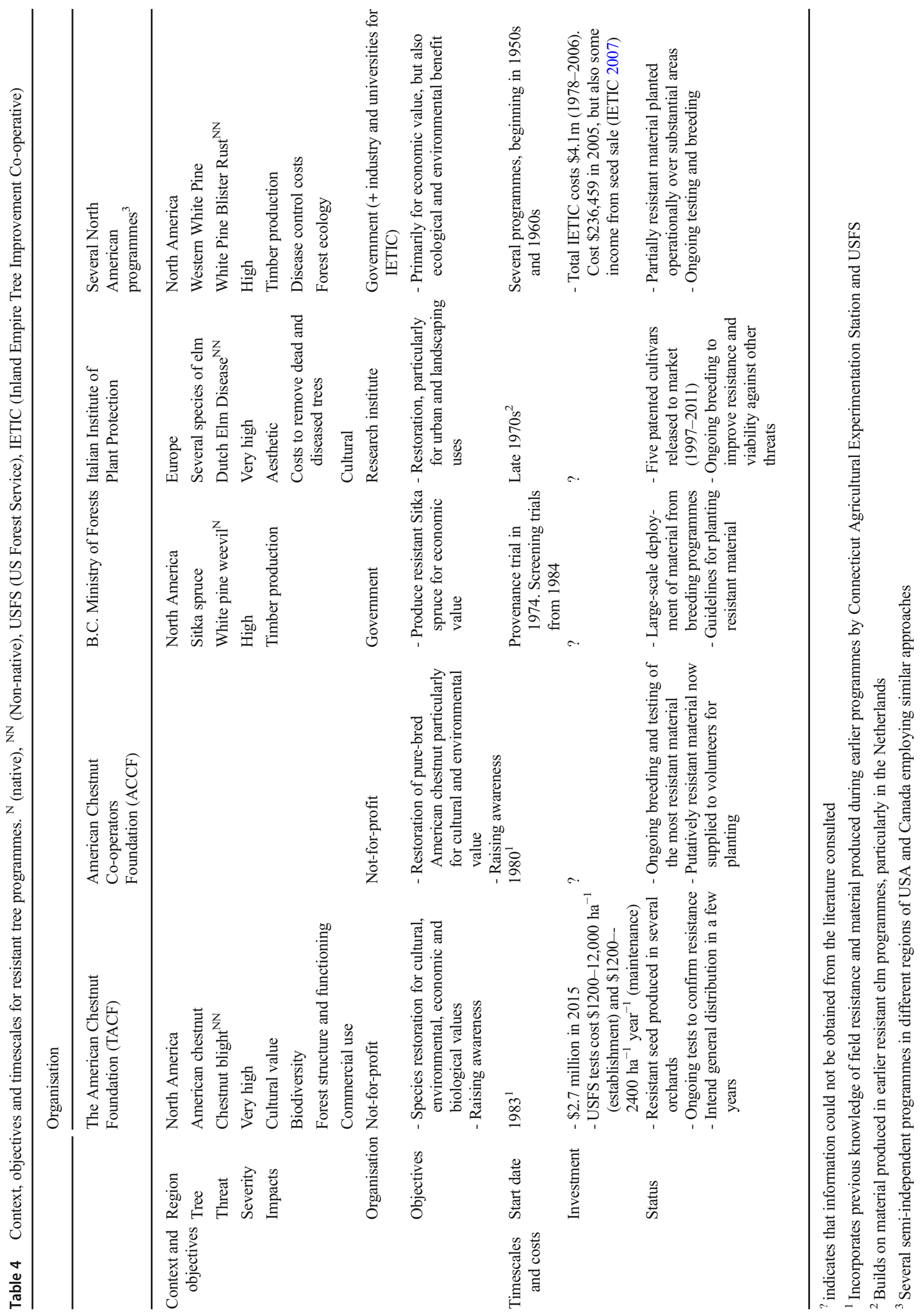




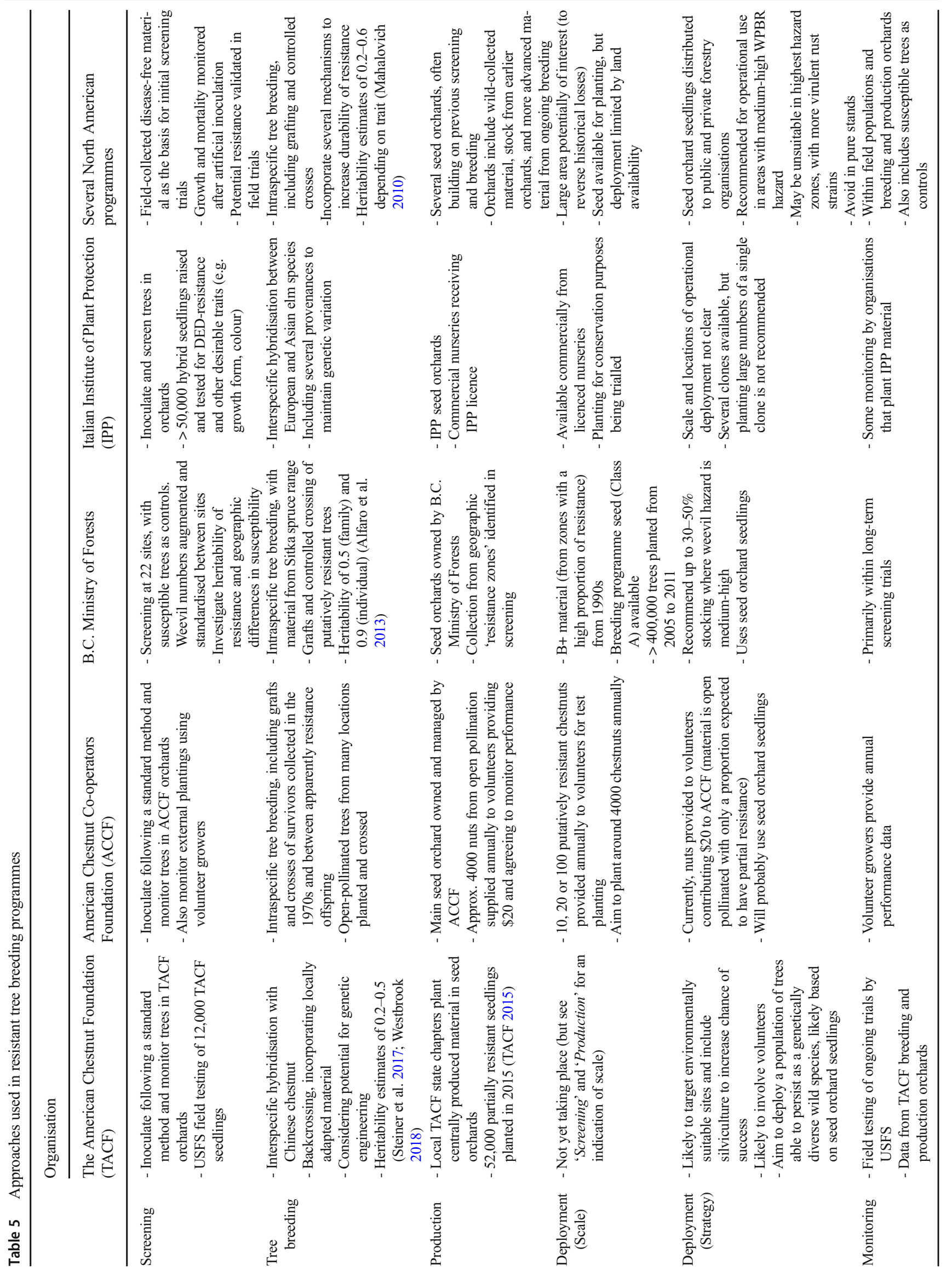


¿ृ:

焉

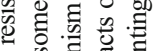

.

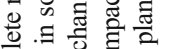

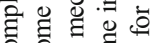

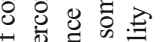

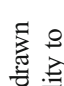

业

E

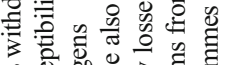

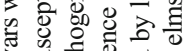

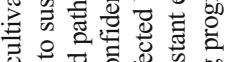

올

可 न त 0

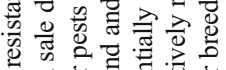

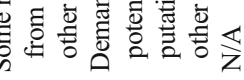

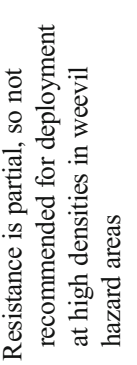

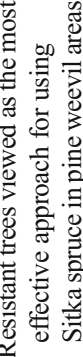

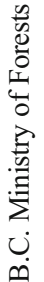

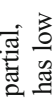

를 mechanisms is hoped to reduce the risk that WPBR subsequently overcomes host resistance, whilst ensuring a broad genetic base that can maintain the capacity to adapt to other environmental pressures (Hunt 2004; Mahalovich 2010; Fig. $5)$.

\subsection{Large-scale production}

Seed orchards are established to produce resistant material for planting. All of the case studies used material from the breeding programme, although seed from regions identified as having a high proportion of resistance can be an interim measure (e.g. Alfaro et al. 2013). Orchards are often on a substantial scale, and therefore require stable funding commitments and co-ordination. In some cases, this is available through existing government forestry infrastructure (e.g. Alfaro et al. 2013). Equally, organisations such as TACF have used extensive communication and outreach to develop a network of volunteer chapters, resulting in many additional seed orchards that complement the central TACF facility (Fitzsimmons et al. 2014; TACF 2015).

\subsection{Planting resistant material-who and how?}

Of the case studies investigated, the Sitka spruce-pine weevil and the WWP-WPBR programmes have both deployed material operationally (Figs. 3 and 5). These programmes have involved long-term government investment and research and are well-suited to centrally co-ordinated planting, which is carried out by government and by private forestry. Notably, partially resistant B+ Sitka spruce from regions identified as having high levels of resistance was used as a low-cost interim deployment measure from the 1990s (Fig. 3), with more fully resistant (Class A) material subsequently planted as the breeding and production programme became established (Alfaro et al. 2013). Outputs from TACF and ACCF American chestnut breeding are subject to ongoing testing, and future deployment may involve working extensively with volunteers (Fitzsimmons et al. 2014). The IPP appears to focus more on the development of resistant elms (rather than large-scale deployment), meaning that this programme is perhaps more reliant on other organisations devising and implementing deployment strategies independently.

Planting strategies often recommend avoiding using monocultures or large blocks of genetically similar individuals, and limiting planting density in zones at high risk from the pest or pathogen (King et al. 2010; Alfaro et al. 2013; Sniezko et al. 2014; Table 3). For example, guidance from Natural Resources Canada advises that if resistant Sitka spruce is planted in high pine weevil hazard zones, a range of genotypes should be used and mixed with other species (https://cfs.nrcan.gc.ca/projects/106; Alfaro et al. 2013). Similarly, planting several WWP genotypes with distinct 
resistance mechanisms is suggested to mitigate the risk from WPBR strains overcoming resistance (Mahalovich 2010; Schwandt et al. 2010; Sniezko et al. 2014), whilst mixing with other native tree species can provide some insurance against losses in zones with high rust hazard (Schwandt et al. 2013). These practices reflect views that monocultures experience greater impacts from species-specific threats than mixed forests, and that genetically similar stands are vulnerable to variants of the pest or pathogen and to changing environmental conditions (Fins et al. 2001; Heppner and Turner 2006; Alfaro et al. 2013; Jacobs et al. 2013). Targeted planting to achieve specific benefits is also sometimes used (e.g. Butterfly Conservation trials of DEDresistant elms to support the conservation of rare butterflies; Brookes 2014). Lastly, silvicultural interventions such as the removal of competitors, pruning to remove or prevent infection, and the use of deer exclosures are important in some programmes (Schwandt et al. 2010; Jacobs et al. 2013; Schwandt et al. 2013) but may be less effective in others (King and Alfaro 2009).

\subsection{Monitoring}

Understanding what happens to resistant trees after planting is important for two reasons (Kearns et al. 2012; Schwandt et al. 2013). Firstly, it increases the chance that any loss of resistance will be detected at an early stage, thereby informing future tree breeding efforts and mitigation measures such as containment. Secondly, it allows the performance of resistant material against other biotic and abiotic pressures to be evaluated. Monitoring to understand general performance is likely to be short to medium-term (i.e. sufficient to represent the range of threats typically experienced by trees). In principle, the breakdown of host resistance could occur at any stage, due to evolution of the local pest/pathogen population or to accidental introduction of a new strain. As such, monitoring for this purpose is perhaps more open-ended, although the regularity and intensity might decline over time if evidence mounts that resistance is durable. The Sitka spruce screening trials from the 1970s onward provide good evidence that weevil attack rates in putatively resistant material are consistently lower than for non-resistant trees over a period encompassing multiple outbreaks and a range of environmental stresses (King and Alfaro 2009). Similar information is available for WWP, with data on infection and mortality rates for several plantings aged $10-30$ years indicating variation in performance across sites and depending on the mechanism of resistance (Fins et al. 2001; Schwandt et al. 2013).

Monitoring data for field plantings is shorter-term in the other case studies considered. TACF are testing the viability of material from later stages of the breeding programme by monitoring large-scale field trials established in collaboration with the US Forest Service: although these trials began in
2009, valuable data have already been collected on the extent and causes of mortality (Clark et al. 2014). Volunteer growers for ACCF also agree to supply annual reports on the performance of planted chestnuts, whilst the field trials conducted by Butterfly Conservation provide useful information on the performance of IPP elms and several other cultivars (Brookes 2014).

\section{Discussion}

\subsection{Successes and problems}

The case studies illustrate that the difficulty of developing resistance can differ markedly between pest-pathogen systems (e.g. depending on the heritability and frequency of resistance in the population), and represents an important constraint in some cases. The long-term viability of resistant trees may also be compromised by three broad threats: (i) the emergence of pest/pathogen strains that overcome resistance, (ii) impacts from the target pest or pathogen if resistance is partial, and (iii) impacts from other current or emerging environmental pressures (e.g. other pests or pathogens, abiotic stresses). These problems have affected resistant tree programmes differently. New strains of WPBR and DED have been highly damaging to some previously resistant WWP and to elms, and impacts on partially resistant WWP trees can occur (Kearns et al. 2012). Trees resistant to specific threats can also be affected by other environmental pressures - e.g. the DED-resistant 'Morfeo' elm was withdrawn from UK nurseries due to the particular susceptibility of this clone to the pathogen elm yellows (https:// www.ashridgetrees.co.uk/morfeo-elm-tree-for-sale, accessed March 72,017; Mittempergher and Santini 2004; Brookes 2014), whilst Phytophthora and deer are the main causes of mortality in trials of blight-resistant American chestnut (Clark et al. 2014). Equally, the Sitka spruce and WWP programmes appear relatively successful, with substantial numbers of resistant trees planted operationally, evidence for viability, and indications that resistant trees may be an effective strategy (Alfaro et al. 2013; Sniezko and Koch 2017). The comparative success of these programmes is probably also a consequence of the level of resistance to pine weevil and WPBR within the respective natural populations (in contrast with the elm and American chestnut examples).

Understanding the demand for resistant trees is a second important consideration. In some cases, scepticism arising from previous failures (and replacement costs) of trees marketed as resistant has reduced demand (Buiteveld et al. 2015). In others, demand may relate more to how the resistant material is produced or performs. For example, DED-resistant elms also need to replicate the aesthetic qualities of the 
affected species, whilst resistant trees of primarily commercial species must maintain timber yields. Where public support or involvement is important (e.g. reliance on volunteers, use of public lands), potentially contentious approaches to developing or deploying resistant trees such as genetic modification or extensive vegetation clearance and silviculture to promote establishment of resistant material should also be very carefully evaluated.

If resistant trees are developed, suitable sites to establish seed orchards and plant material are still needed. Land availability can therefore be an impediment, particularly where restoration is involved and the affected species has been displaced by other trees (Fitzsimmons et al. 2014). Indeed, some have argued that re-establishing species such as WWP extensively will require the potentially controversial clearance of large areas of vegetation, alongside silviculture to promote the regeneration and spread of resistant trees (Fins et al. 2001; Schwandt et al. 2010).

\subsection{Timescales and costs}

The case studies suggest at least $10-20$ years are required before operational planting of resistant material (Figs. 1, 2, 3, 4 and 5), which itself can be protracted (Schwandt et al. 2010). Newer programmes could be expedited by technological improvements (e.g. genomic methods for screening and breeding; Steiner et al. 2017) and by planting partially resistant material as an interim measure (Alfaro et al. 2013), but even under optimal circumstances resistant tree programmes appear to be a medium-term strategy, with many not yet reaching the stage of field planting (Figs. 1, 2, 3, 4 and 5; Table 1, see also http:// www.fao.org/forestry/26462/en/). Timescales also reflect the emphasis placed on testing and breeding (to demonstrate viability) compared with the pressure to move rapidly to large-scale planting (to mitigate impacts). These priorities can be pursued simultaneously to an extent, but the balance is influenced by several factors - e.g. willingness of stakeholders to take risks, urgency of the threat, potential benefits from resistant trees, consequences of unanticipated damage and mortality. For example, there appears to be a willingness to make use of resistant Sitka spruce and WWP, perhaps reflecting the potential benefits to forestry, general confidence that the material is viable, and an assessment that some losses due to partial resistance are still acceptable. Lastly, timescales sometimes reflect the need to meet objectives beyond producing trees that are resistant to a specific threat, such as incorporating other desirable traits, maintaining genetic variation, or using particular tree breeding approaches that ensure the results meet the objectives of the programme (e.g. backcrossing by TACF).

The investment in resistant tree programmes was not always clear in the available literature, although as an indication the US Forest Service spent an estimated \$6.9 million on American chestnut restoration research from 2003 to 2013 (Clark et al. 2014), whilst TACF accounts have annual expenditure of \$2-3 million (TACF 2015). TACF costs are not necessarily representative because of the broad scope of the work (large-scale restoration, a complex tree breeding programme, and substantial public outreach). Indeed, the only other case

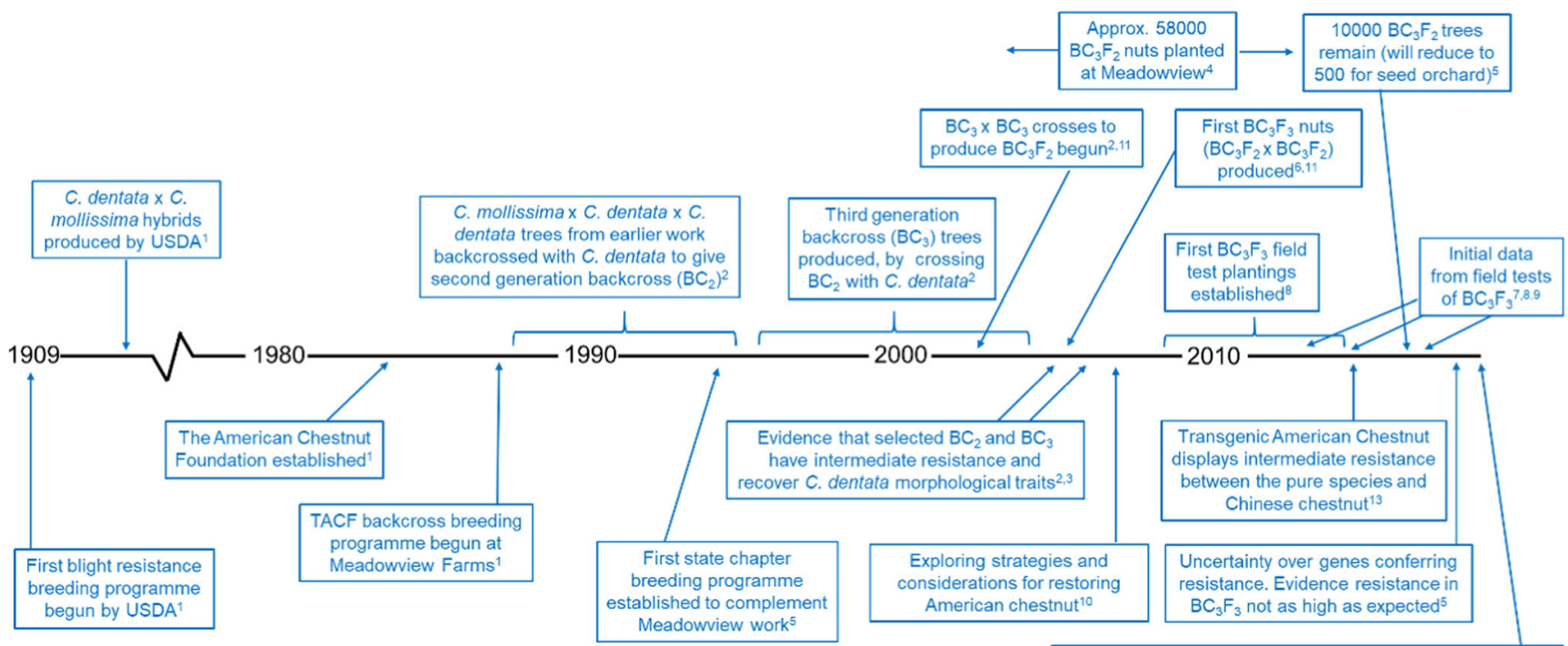

TACF breeding strategy indicates intention to incorporate GM material, subject to regulatory approval ${ }^{14}$

16 state chapters established. Approx. 586 plantations on 335 ha managed, with thousands of chestnuts planted annually, largely by volunteers ${ }^{5,12}$

Fig. 1 Timeline indicating prominent events in American chestnut (Castanea dentata) resistance programme carried out by The American Chestnut Foundation (TACF). Numbered references are: ${ }^{1}$ Jacobs et al. (2013). ${ }^{2}$ Hebard (2005b). ${ }^{3}$ Diskin et al. (2006). ${ }^{4}$ Hebard (2012).
${ }^{5}$ Steiner et al. (2017). ${ }^{6}$ Hebard (2005a). ${ }^{7}$ Clark et al. (2011). ${ }^{8}$ Clark et al. (2014). ${ }^{9}$ Clark et al. (2016). ${ }^{10}$ Jacobs (2007). ${ }^{11}$ TACF Annual Report (2014). ${ }^{12}$ TACF Annual Report (2016). ${ }^{13}$ Newhouse et al. (2014). ${ }^{14}$ Westbrook (2018) 


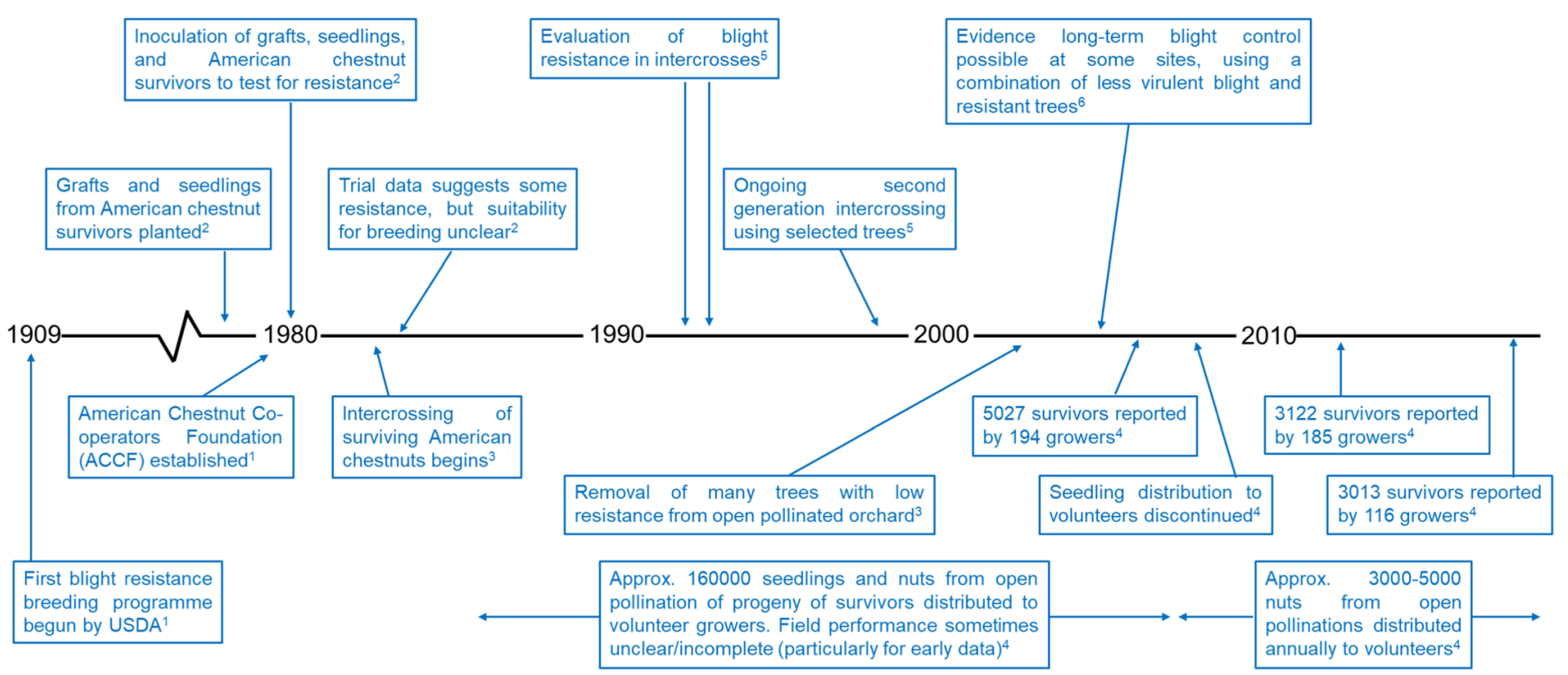

Fig. 2 Timeline indicating prominent events in American chestnut (Castanea dentata) breeding programme carried out by the American Chestnut Co-operators Foundation (ACCF). Numbered references are: ${ }^{1}$ Jacobs et al. (2013). ${ }^{2}$ Griffin et al. (1983). ${ }^{3} \mathrm{http}: / /$ www.accf-online.org/

for which we found clear cost estimates was the WWP-WPBR programme carried out by the Inland Empire Tree Improvement Co-operative (IETIC), which reported a total cost of $\$ 4.1$ million from 1978 to 2006 and a cost of $\$ 236,459$ in 2005 (IETIC 2007). Although it is difficult to generalise on costs beyond emphasising that the screening, breeding and production stages of resistant tree programmes require sustained funding, these two examples give some indication of the potential range and duration of investment. It is also notable that seed sales and other activities provided some accf1.htm. ${ }^{4} \mathrm{http} / / / \mathrm{www}$.accf-online.org/breed.html. ${ }^{5} \mathrm{ACCF}$ Newsletters (2002-2017; http://www.accf-online.org/news.html). ${ }^{6}$ Griffin et al. (2005)

income for IETIC: the former was variable but returned $\$ 40$ 50,000 in some years (IETIC 2007). Sources of financial support reflect the differing aims of resistant tree programmes, and include donations, grants, and volunteer time (TACF, ACCF) and government funding (Sitka spruce, WWP). An evaluation of the potential costs, benefits (including noneconomic values), funding sources and alternative mitigation measures at an early stage could help to inform decisions over whether a proposed resistant tree programme is likely to be an effective option.

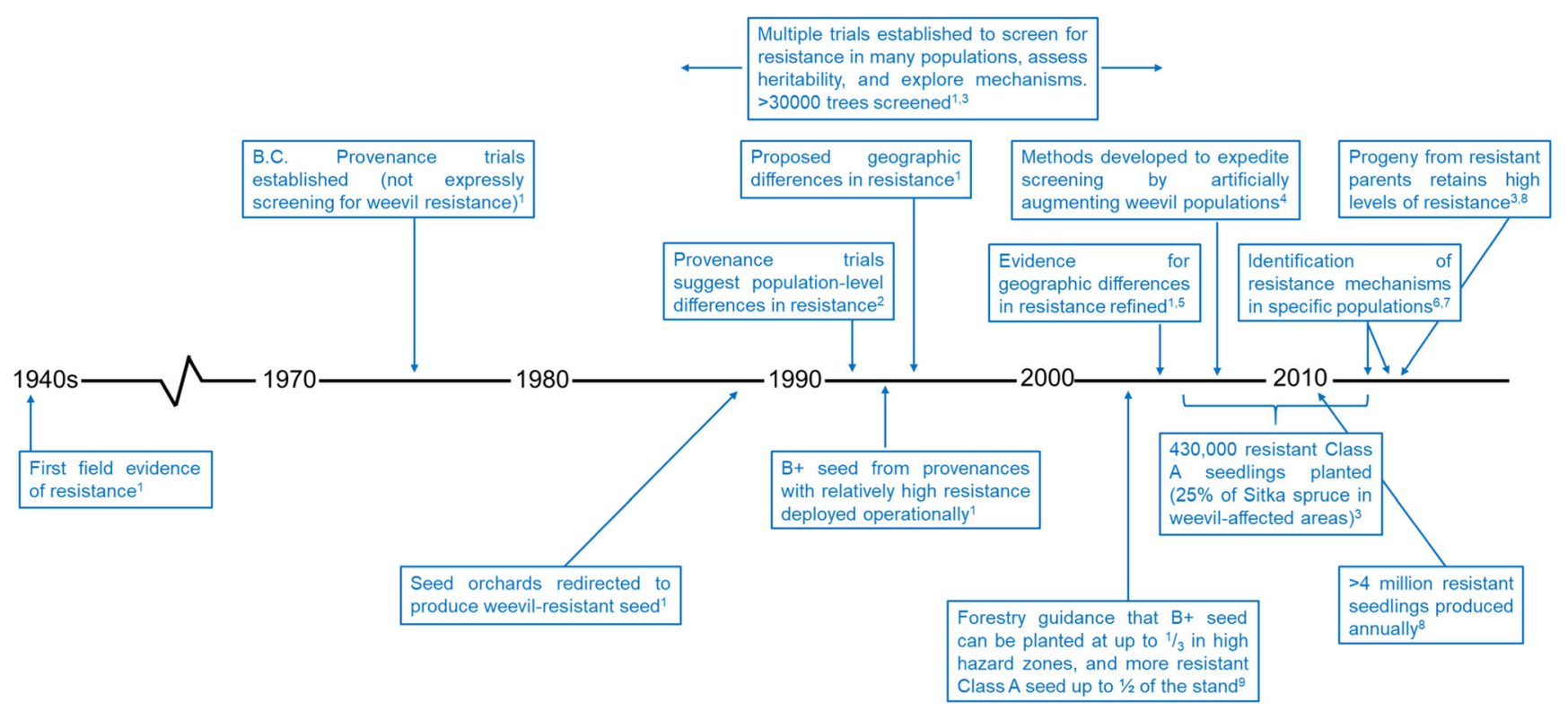

Fig. 3 Timeline indicating prominent events in the Sitka spruce (Picea sitchensis) breeding programme carried out by the British Columbia (B.C.) Ministry of Forests. Numbered references are: ${ }^{1}$ King and Alfaro
(2009). ${ }^{2}$ Ying (1991). ${ }^{3}$ Alfaro et al. (2013). ${ }^{4}$ Alfaro et al. (2008). ${ }^{5}$ King et al. (2004). ${ }^{6}$ King et al. (2011). ${ }^{7}$ Moreira et al. (2012). ${ }^{8}$ Alfaro and King (2012). ${ }^{9}$ Heppner and Turner (2006) 


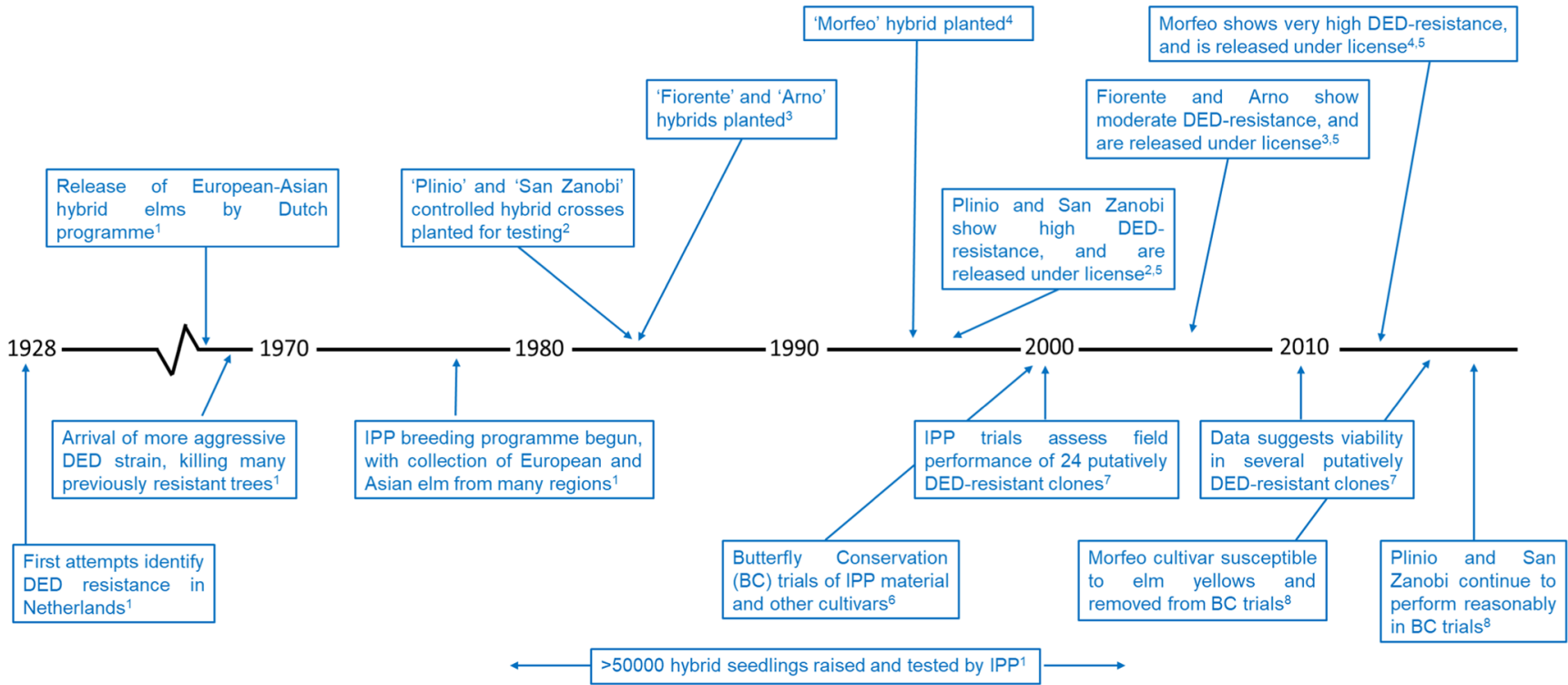

Fig. 4 Timeline indicating prominent events in the elm (Ulnus spp.) breeding programme carried out by the Italian Institute of Plant Protection (IPP). Numbered references are: ${ }^{1}$ Mittempergher and Santini

\subsection{What makes a successful resistant tree programme?}

Comparing the case studies highlights several points that may influence the success of resistant tree programmes:

- The most effective programmes have had central coordination and long-term commitment, e.g. by government
(2004). ${ }^{2}$ Santini et al. (2002). ${ }^{3}$ Santini et al. (2007). ${ }^{4}$ Santini et al. (2011). ${ }^{5}$ Santini et al. (2012). ${ }^{6}$ Brookes (2010). ${ }^{7}$ Santini et al. (2010). ${ }^{8}$ Brookes (2014)

and/or well-funded NGOs. This arises (i) if the species has a high timber value and/or (ii) if the species (or other benefits associated with it) has a high cultural/societal value and so can generate substantial public support. If neither of these criteria are met, a lack of resources or co-ordination may lead to piecemeal or incomplete approaches, or the proliferation of putatively resistant material from different sources with little guidance on field performance and viability.

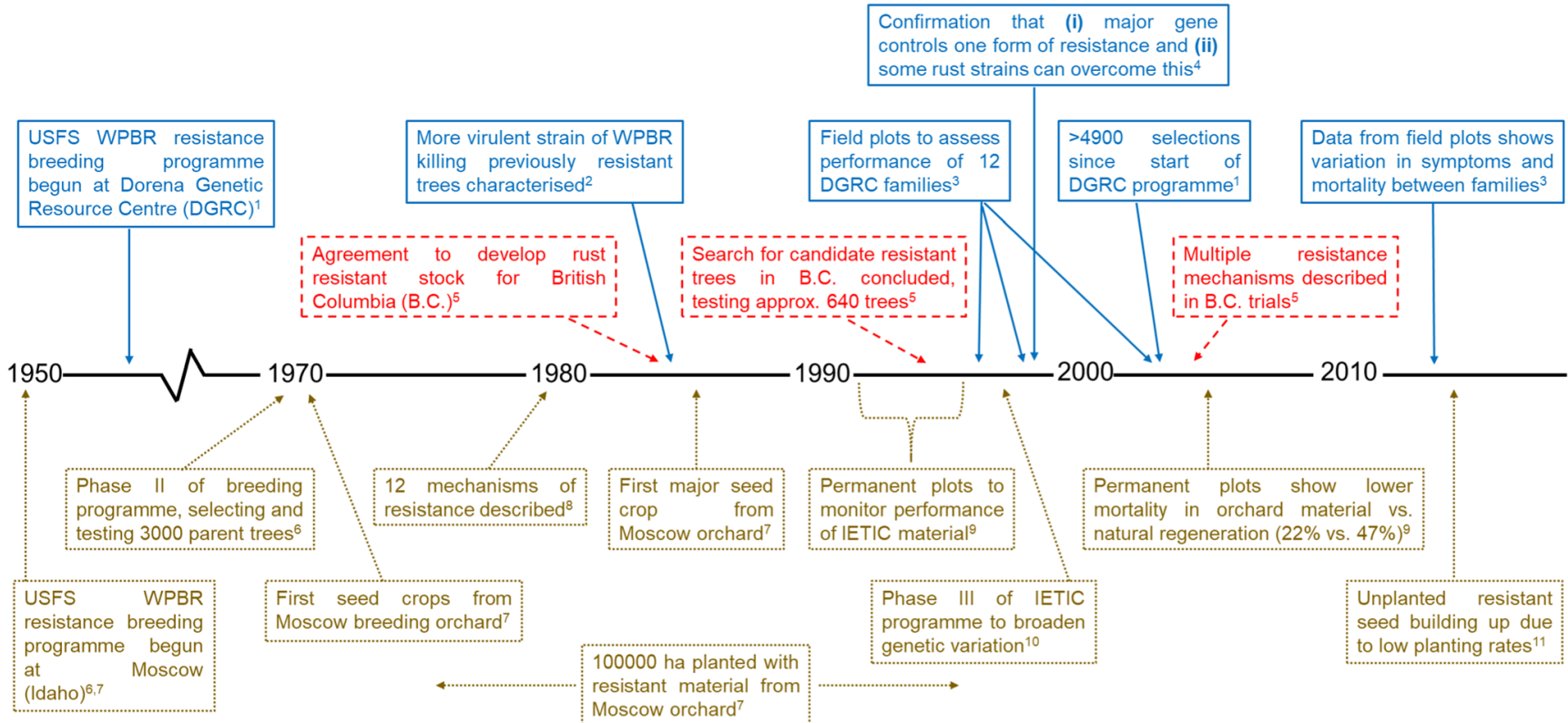

Fig. 5 Timeline indicating prominent events in Western White Pine (WWP) breeding programmes carried out in North America. Programmes shown: Dorena Genetic Resource Centre (blue text, solid lines); British Columbia Ministry of Forests (red text, dashed lines); Inland Empire Tree Improvement Co-operative (brown text, dotted lines).
Numbered references are: ${ }^{1}$ King et al. (2010). ${ }^{2}$ McDonald et al. (1984). ${ }^{3}$ Sniezko et al. (2012). ${ }^{4}$ Kinloch et al. (1999). ${ }^{5}$ Hunt (2004). ${ }^{6}$ Bingham (1983). ${ }^{7}$ Fins et al. (2001). ${ }^{8} \mathrm{Hoff}$ and McDonald (1980). ${ }^{9}$ Kearns et al. (2012). ${ }^{10}$ Mahalovich (2010). ${ }^{11}$ Schwandt et al. (2013) 
- Success is influenced by the level of resistance present in individual trees, the frequency of resistance in the population, and the heritability of resistance. As such, this represents important contextual knowledge for guiding the choice of approach and the expectations.

- It is important to consider current and potential future risks to the species in addition to the target pest or pathogenthe benefits of trees resistant to a specific threat are negated if it is susceptible to other threats.

- Demand should be evaluated, and the priorities of potential supporters and end users should inform the methods used to produce resistant trees.

- Operational deployment should balance the urgency of the threat with the consequences if resistant material does not perform as hoped. The case studies presented here are responding to situations with either very extensive mortality or chronic impacts, but the urgency may differ for an emerging pest or pathogen.

- Deployment strategies should be informed by the risks of imposing a strong selection pressure on the pest or pathogen to evolve to overcome host resistance, and by potential impacts on partially resistant trees.

- Continued monitoring of field performance is important for evaluation, and can help to identify and mitigate emerging threats (e.g. new pathogen strains)

\section{Conclusions}

The approaches and the outcomes for resistant tree programmes are sometimes not well-documented, or may be dispersed across the grey literature (e.g. technical reports, conference proceedings, websites, management guidelines). Greater communication and accessibility of information would therefore help to better generalise on approaches, timescales and effectiveness. Nonetheless, the case studies illustrate that resistant tree programmes are medium to long-term approaches that have varying levels of success and typically require considerable investment. Expectations should reflect these realities and the challenges of the specific host-pest/pathogen system. Equally, the case studies also show that adequately resourced and well-planned resistant tree programmes can form an important part of strategies to mitigate impacts from pests and pathogens.

Acknowledgements We are very grateful to the Department for Environment, Food and Rural Affairs (Defra) for providing funding through the Future-Proofing Plant Health (FPPH) project. We also thank Richard Buggs, Cécile Robin and two anonymous reviewers for very helpful and constructive comments, as well as those involved in FPPH from a range of organisations including JNCC, Forest Research and Defra.
Funding This work was supported by the Department for Environment, Food and Rural Affairs (Defra) as part of the Future-Proofing Plant Health project.

Data availability This study did not produce novel data, but the extracted information is fully presented in the tables provided.

\section{Compliance with ethical standards}

Conflict of interest The authors declare that they have no conflict of interest.

\section{References}

Alfaro, RI, King, JN (2012) Screening Sitka spruce for resistance to weevil damage in British Columbia. In: Sniezko RA, Yanchuk AD, Kliejunas JT, Palmieri KM, Alexander JM, Frankel SJ (tech coords) Proceedings of the fourth international workshop on the genetics of host-parasite interactions in forestry: disease and insect resistance in forest trees. USDA Forest Service General Technical Report PSW-GTR-240, pp 271-275

Alfaro RI, King JN, Brown RG, Buddingh SM (2008) Screening of Sitka spruce genotypes for resistance to the white pine weevil using artificial infestations. For Ecol Manag 255:1749-1758

Alfaro RI, King JN, van Akker L (2013) Delivering Sitka spruce with resistance against white pine weevil in British Columbia, Canada. For Chron 89:235-245

Aukema BH, Carroll AL, Zhu J, Raffa KF, Sickley TA, Taylor SW (2006) Landscape level analysis of mountain pine beetle in British Columbia, Canada: spatiotemporal development and spatial synchrony within the present outbreak. Ecography 29:427-441

Bentz SE, Montgomery ME, Olsen RT (2008) Resistance of hemlock species and hybrids to hemlock woolly adelgid. In: Onken B, Reardon R (eds) Fourth Symposium on Hemlock Woolly Adelgid in the Eastern United States. USDA Forest Service FHTET-200801, pp 137-139

Bernier L (2017) Genome-wide analyses of the Dutch elm disease fungi. In: Pinchot CC, Knight KS, Haugen LM, Flower CE, Slavicek, JM (eds) Proceedings of the American elm restoration workshop 2016; USDA Forest Service General Technical Report NRS-P-174, pp 620

Bingham RT (1983) Blister rust resistant western white pine for the Inland Empire: the story of the first 25 years of the research and development program. USDA Forest Services General Technical Report INT146. Intermountain Forest \& Range Experiment Station, Ogden

Boraks A, Broders KD (2014) Butternut (Juglans cinerea) health, hybridisation, and recruitment in the northeastern United States. Can J For Res 44:1244-1252

Boyd IL, Freer-Smith PH, Gilligan CA, Godfray HCJ (2013) The consequences of tree pests and diseases for ecosystem services. Science 342:1235773. https://doi.org/10.1126/science. 1235773

Brasier CM (2008) The biosecurity threat to the UK and global environment from international trade in plants. Plant Pathol 57:792-808

Brookes A (2010) Disease-resistant elms. Butterfly Conservation trials report 2010. http://perigordvacance.typepad.com/files/2010-elmreport-1.pdf. Accessed 8 Mar 2017

Brookes A (2014) Disease-resistant elms. Butterfly Conservation trials report 4th revision http://www.hantsiow-butterflies.org.uk/ downloads/2014\%20Elm\%20Report.pdf. Accessed 8 Mar 2017 
Buiteveld J, van der Werf D, Hiemstra JA (2015) Comparison of commercial elm cultivars and promising unreleased Dutch clones for resistance to Ophiostoma novo-ulmi. iForest 8:158-164

Clark SL, Schlarbaum SE, Saxton AM, Hebard FV (2011) Making history: field testing of blight-resistant American chestnut. In: Fei S, Lhotka JM, Stringer JW, Gottschalk KW, Miller GW (eds) Proceedings of the $17^{\text {th }}$ Central Hardwood Conference. USDA Forest Services General Technical Report NRS-P-78, pp 656-657

Clark SL, Schlarbaum SE, Pinchot CC, Anagnostakis SL, Saunders MR, Thomas-Van Gundy M et al (2014) Reintroduction of American chestnut in the National Forest System. J For 112:502-512

Clark SL, Schlarnbaum SE, Saxton AM, Hebard FC (2016) Establishment of American chestnut (Castanea dentata) bred for blight (Cryphonectria parasitica) resistance: influence of breeding and nursery grading. New For 47:243-270

Defra (2013) Chalara Management Plan. www.gov.uk/government/ publications/chalara-management-plan. Accessed online 8 Mar 2017

Diskin M, Steiner KC, Hebard FV (2006) Recovery of American chestnut characteristics following hybridisation and backcross breeding to restore blight-ravaged Castanea dentata. For Ecol Manag 223: $439-447$

FAO (2013) http://www.fao.org/forestry/26460/en/. Accessed online 7 Mar 2017

Fins L, Byler J, Ferguson D, Harvey A, Mahalovich MF, McDonald GI et al (2001) Return of the giant: restoring white pine ecosystems by breeding and aggressive planting of blister rust-resistant white pines. Station Bulletin 72. University of Idaho Forest, Wildland and Range Experiment Station

Fitzsimmons S, Gurney K, Georgi L, Hebard F, Brinckman M, Saielli T (2014) Regionally adapted seed orchards within TACF's state chapters. J Amer Chestnut Found 28:15-19

Freer-Smith PH, Webber JF (2015) Tree pests and diseases: the threat to biodiversity and the delivery of ecosystem services. Biodivers Conserv 26:3167-3181

Griffin GJ, Hebard FV, Wendt RW, Elkins JR (1983) Survival of American chestnut trees: evaluation of blight resistance and virulence to Endothia parasitica. Phytopathology 73:1084-1092

Griffin GJ, Elkins JR, McCurdy D, Griffin SL (2005) Integrated use of resistance, hypovirulence, and forest management to control blight on American chestnut. In: Steiner KC, Carlson JE (eds) Proc of conf. on restoration of American chestnut to forest lands. Natural Resource Report NPS/NCR/CUE/NRR-2006/001. National Park Service, Washington, DC, pp 91-107

Hebard FV (2005a) The backcross breeding programme of The American Chestnut Foundation. In: Proc of conf. on restoration of American chestnut to forest lands. Natural Resource Report NPS/NCR/CUE/ NRR-2006/001, National Park Service, Washington, DC, pp 61-77

Hebard FV (2005b) Notes from Meadowview 2004-2005. Journal of the American Chestnut Foundation 19:16-29

Hebard FV (2012) The American Chestnut Foundation Breeding Program. In: Sniezko RA, Yanchuk AD, Kliejunas JT, Palmieri KM, Alexander JM, Frankel SJ (tech coords) Proceedings of the fourth international workshop on the genetics of host-parasite interactions in forestry: disease and insect resistance in forest trees. USDA Forest Service General Technical Report PSW-GTR-240, pp 221-234

Heppner D, Turner J (2006) British Columbia's coastal forests: spruce weevil and western spruce weevil budworm forest health stand establishment decision aids. BC Journal of Ecosystems and Management 7:45-49

Hoff RJ, McDonald GI (1980) Improving rust-resistant strains of inland western white pine. USDA Forest Service Research Paper INT-245. Intermountain Forest \& Range Experiment Station, Ogden

Hunt RS (2004) Blister rust resistant western white pines for British Columbia. Canadian Forest Service Information Report BC-X-397
IETIC (2007) The Inland Empire Tree Improvement Cooperative. In: 28th Progress report. Inland Empire Tree Improvement Cooperative, Moscow

Ivkovic M, Baltunis B, Gapare W, Sasse J, Durkowski G, Elms S et al (2011) Breeding against Dothistroma needle blight of radiata pine in Australia. Can J For Res 40:1653-1660

Jacobs DF (2007) Toward development of silvical strategies for forest restoration of American chestnut (Castanea dentata) using blightresistant hybrids. Biol Conserv 137:497-506

Jacobs DF, Dalgleish HJ, Nelson CD (2013) A conceptual framework for restoration of threatened plants: the effective model of American chestnut (Castanea dentata) reintroduction. New Phytol 197:378393

Kearns HSJ, Ferguson BA, Schwandt JW (2012) Performance of rustresistant western white pine in operational plantations in northern Idaho: 1995-2006. USDA Forest Service Report No 12-03

King JN, Alfaro RI (2009) Developing Sitka spruce populations for resistance to the white pine weevil: summary of research and breeding program. B.C. Min. For. Range, For. Sci. Prog. Technical Report 050

King, JN, Alfaro, RI, Cartwright, C (2004) Genetic resistance of Sitka spruce (Picea sitchensis) populations to the white pine weevil (Pissodes strobi): distribution of resistance. Forestry 77:269-278

King JN, David A, Noshad D, Smith J (2010) A review of genetic approaches to the management of blister rust in white pines. For Pathol 40:292-313

King JN, Alfaro RI, Grau Lopez M, van Akker L (2011) Resistance of Sitka spruce (Picea stichensis (Bong.) Carr.) to white pine weevil (Pissodes strobi Peck): characterising the bark defence mechanisms of resistant populations. Forestry 84:83-91

Kinloch BB, Sniezko RA, Barnes GD, Greathouse TE (1999) A major gene for resistance to white pine blister rust in Western white pine from the Western cascade range. Phytopathology 89:861-867

Koch JL (2010) Beech bark disease: the oldest 'new' threat to American beech in the United States. Outlooks on Pest Management 21:64-68

Koch JL, Mason ME, Carey DW (2012a) Screening for resistance to beech bark disease: improvements and results from seedlings and grafted field selections. F, Ghelardini L (2012) The Italian elm breeding program for Dutch Elm Disease resistance. In: Sniezko RA, Yanchuk AD, Kliejunas JT, Palmieri KM, Alexander JM, Frankel SJ (tech coords) Proceedings of the fourth international workshop on the genetics of host-parasite interactions in forestry: disease and insect resistance in forest trees. USDA Forest Service General Technical Report PSW-GTR-240, pp 196-208

Koch JL, Carey DW, Knight KS, Poland TS, Herms DA, Mason ME (2012b) Breeding strategies for the development of emerald ash borer-resistant North American ash. In: Sniezko RA, Yanchuk AD, Kliejunas JT, Palmieri KM, Alexander JM, Frankel SJ (tech coords) Proceedings of the fourth international workshop on the genetics of host-parasite interactions in forestry: disease and insect resistance in forest trees. USDA Forest Service General Technical Report PSWGTR-240, pp 235-239

Laffin RD, Langor DW, Sperling FAH (2004) Population structure and gene flow in the white pine weevil. Ann Entomol Soc Am 97:949 956

Mahalovich MF (2010) USA Inland Northwest western white pine breeding and restoration program: history, current and future directions. http://dnrc.mt.gov/divisions/forestry/docs/assistance/pests/ miscellaneous-publications/mahalovich-2010.pdf/at_download/file. Accessed 22 Aug 2018

McDonald GI, Hansen EM, Osterhaus CA, Samman S (1984) Initial characterisation of a new strain of Cronartium ribicola from the Cascade mountains of Oregon. Plant Dis 68:800-804

McDonald G, Zambino P, Sniezko R (2004) Breeding rust-resistant fiveneedle pines in the Western United States: lessons from the past and a look to the future. In: Sniezko RA, Samman S, Schlarbaum SE, 
Kriebel HB (eds) Breeding and genetic resources of five-needle pines: growth, adaptability and pest resistance. USDA Forest Service Proceedings RMRS-P-32, pp 28-50

McKenna JR, Ostry ME, Woeste K (2011) Screening butternut and butternut hybrids for resistance to butternut canker. In: Fei S, Lhotka JM, Stringer JW, Gottschalk KW, Miller GW (eds) Proceedings of the $17^{\text {th }}$ Central Hardwood Conference. USDA Forest Services General Technical Report NRS-P-78. pp 460-474

Michler CH, Pijut PM, Jacobs DF, Meilan R, Woeste KE, Ostry ME (2005) Improving disease resistance of butternut (Juglans cinerea), a threatened fine hardwood: a case for single-tree selection through genetic improvement and deployment. Tree Physiol 26:121-128

Mittempergher L, Santini A (2004) The history of elm breeding. Inv Agrar-Sist Rec F 13:161-177

Montgomery ME, Bentz SE, Olsen RT (2009) Evaluation of hemlock (Tsuga) species and hybrids for resistance to Adelges tsugae (Hemiptera: Adelgidae) using artificial infestation. J Econ Entomol 102:1247-1254

Moreira X, Alfaro RI, King JN (2012) Constitutive defences and damage in Sitka spruce progeny obtained from crosses between white pine weevil resistant and susceptible parents. Forestry 85:87-97

Newhouse AE, Polin-McGuigan LD, Baier KA, Valletta KER, Rottmann WH, Tschaplinski TJ et al (2014) Transgenic American chestnuts show enhanced blight resistance and transmit the trait to $\mathrm{T} 1$ progeny. Plant Sci 228:88-97

Oten KLF, Merkle SA, Jetton RM, Smith BC, Talley ME, Hain FP (2014) Understanding and developing resistance in hemlocks to the hemlock woolly adelgid. Southeast Nat 13:147-167

Pautasso M, Doring TF, Garbelotto M, Pellis L, Jeger MJ (2012) Impacts of climate change on plant diseases - opinions and trends. Eur J Plant Pathol 133:295-313

Perry A, Wachowiak W, Brown AC, Ennos RA, Cottrell JE, Cavers S (2016) Substantial heritable variation of susceptibility to Dothistroma septosporum within populations of native British Scots pine (Pinus sylvestris). Plant Pathol 65:987-996

Santini A, Fagnani A, Ferrini F, Mittempergher L (2002) San Zanobi and Plinio elm trees. Hortscience 37:1139-1141

Santini A, Fagnani A, Ferrini F, Ghelardini L, Mittempergher L (2007) 'Fiorente' and 'Arno' elm trees. Hortscience 42:712-714

Santini A, Pecori F, Pepori AL, Ferrini GL (2010) Genotype x environment interaction and growth stability of several elm clones resistant to Dutch elm disease. For Ecol Manag 260:1017-1025

Santini A, Pecori F, Pepori A, Brookes A (2011) 'Morfeo' elm: a new variety resistant to Dutch elm disease. For Pathol 42:171-176

Santini A, Pecori F, Ghelardini L (2012) The Italian elm breeding program for Dutch elm disease resistance. In: Sniezko RA, Yanchuk AD, Kliejunas JT, Palmieri KM, Alexander JM, Frankel SJ (tech coords) Proceedings of the fourth international workshop on the genetics of host-parasite interactions in forestry: disease and insect resistance in forest trees. USDA Forest Service General Technical Report PSW-GTR-240, pp 326-335

Schwandt JW, Lockman IB, Kliejunas JT, Muir JA (2010) Current health issues and management strategies for white pines in the western United States and Canada. For Pathol 40:226-250

Schwandt J, Kearns H, Byler J (2013) White pine blister rust general ecology and management. USDA Forest Services Insect and Disease Management Series 14.2: 1-25
Sniezko RA (2006) Resistance breeding against non-native pathogens in forest trees - current successes in North America. Can J Plant Pathol 28:S270-S279

Sniezko RA, Koch J (2017) Breeding trees resistant to insects and diseases: putting theory into application. Biol Invasions 19:3377-3400

Sniezko RA, Kegley AJ, Danchok R (2008) White pine blister rust resistance in North American, Asian, and European species - results from artificial inoculation trials in Oregon. Ann For Res 51:53-66

Sniezko RA, Danchok R, Hamlin J, Kegley A, Long S, Mayo J (2012) White pine blister rust resistance of 12 western white pine families at three field sites in the Pacific Northwest. In: Sniezko RA, Yanchuk AD, Kliejunas JT, Palmieri KM, Alexander JM, Frankel SJ (tech coords) Proceedings of the fourth international workshop on the genetics of host-parasite interactions in forestry: disease and insect resistance in forest trees. USDA Forest Service General Technical Report PSW-GTR-240, pp 356-367

Sniezko RA, Smith J, Liu J-J, Hamelin RC (2014) Genetic resistance to fusiform rust in southern pines and white pine blister rust in white pines - a contrasting tale of two rust pathosystems - current status and future prospects. Forests 5:2050-2083

Steiner KC, Westbrook JW, Hebard FV, Georgi LL, Powell WA, Fitzsimmons SF (2017) Rescue of American chestnut with extraspecific genes following its destruction by a naturalised pathogen. New For 48:317-336

The American Chestnut Foundation Annual Report (2014) https://www. acf.org/wp-content/uploads/2016/05/TACF_2014AR_web.pdf? x27388. Accessed 6 Mar 2017

The American Chestnut Foundation Annual Report (2015). https:/www. acf.org/wp-content/uploads/2016/05/TACF_AnnualReport2015 Finalrev_web.pdf?x27388. Accessed 6 Mar 2017

The American Chestnut Foundation Germplasm Agreement Summary (2016) https://www.acf.org/wp-content/uploads/2016/05/ summary_of_germplasm_agreement.pdf. Accessed 7 Mar 2017

Townsend AM, Bentz SE, Douglass LW (2005) American elm clones for tolerance to Dutch elm disease. J Environ Hortic 23:21-24

Vasaitis R, Enderle R (2017) Dieback of European ash (Fraxinus spp.): consequences and guidelines for sustainable management. The Report on European Cooperation in Science \& Technology Action FP1103 FRAXBACK. Swedish University of Agricultural Sciences, Uppsala

Westbrook J (2018) Merging backcross breeding and transgenic blight resistance to accelerate restoration of the American chestnut. The American Chestnut Foundation's breeding and selection plan 2015-2025. Revised 12th February 2018

Woeste K, Farless L, Ostry M, McKenna J, Weeks S (2009) A forest manager's guide to butternut. North J Appl For 26:9-14

Woodcock P, Cottrell JE, Buggs RJA, Quine CP (2018) Mitigating pest and pathogen impacts using resistant trees: a framework and overview to inform development and deployment. Forestry 91:1-16

Ying CC (1991) Genetic resistant to the white pine weevil in Sitka spruce. BC Minist For Res Branch Research Note 106

Publisher's note Springer Nature remains neutral with regard to jurisdictional claims in published maps and institutional affiliations. 